\title{
Green Economy and Renewable Energy Focusing on the Biomass Energy Source
}

\author{
Mohammed Ebrahim Hussien ${ }^{1}$, Chamhuri Siwar ${ }^{1}$, Rashidah Zainal Alam ${ }^{1}$, Abdul Hamid Jafar ${ }^{2} \&$ Norasikin \\ Ahmad Ludin ${ }^{3}$ \\ ${ }^{1}$ Institute for Environment and Development (LESTARI), Universiti Kebangsaan Malaysia (UKM), Malaysia \\ ${ }^{2}$ Faculty of Economics and Management, Universiti Kebangsaan Malaysia (UKM), Malaysia \\ ${ }^{3}$ Solar Energy Research Institute (SERI), Universiti Kebangsaan Malaysia (UKM), Malaysia \\ Correspondence: Chamhuri Siwar, Institute for Environment and Development (LESTARI), Universiti \\ Kebangsaan Malaysia (UKM), Malaysia. Tel: 60-3-8921-4154. E-mail: csiwar@ukm.edu.my
}

\author{
Received: February 5, 2016 Accepted: February 25, 2016 Online Published: May 30, 2016 \\ doi:10.5539/jsd.v9n3p56 URL: http://dx.doi.org/10.5539/jsd.v9n3p56
}

\begin{abstract}
Since conventional energy resources are major source of $\mathrm{CO}_{2}$ emission, over reliance on fossil fuels has raised questions on environmental sustainability. On way to address these multi-faceted issues of conventional energy sources, the sustainability of energy and environment is through the green economy approach. As such, this paper aims to discuss the concept of green economy in relation with renewable energy. The interdependence of green economy and environmental quality as well as the compatibility of green economy approach with the notion of sustainable development are demonstrated in the paper. Green economy approach fulfils the methodological gaps that exist in the growth models. It is believed that the best economic tool to attain sustainable development goals is by integrating social, economic and environmental elements. Furthermore, energy is believed to be a significant player in determining the greenness of the economy and sustainability as it has economic and environmental value. In addition, this study illustrates the significance of biomass energy resource and $\mathrm{CO}_{2}$ emissions from fossil fuel combustion. The illustration framework justifies that biomass is the determinant renewable energy source to be a proxy for renewable energy resources. Similarly, it justifies that $\mathrm{CO}_{2}$ emission of energy sector is considerably significant to represent the $\mathrm{CO}_{2}$ emissions of the atmosphere.
\end{abstract}

Keywords: biomass, energy, environment, green economy, sustainability

\section{Introduction}

The relationship between economic growth and environment, traditionally, was considered as a trade-off relation. In addition, the production process used to focus solely on the material achievement of economic growth rather than valuation of environmental resources. However, the notion of sustainable development is a holistic and system approach of development thinking that focuses on the quantitative economic growth of the country without compromising the quality of the environment as well as not jeopardizing the need of future generation. In line with this, the energy sector is one of the driving forces towards sustainable development of the nation due to its advantage of having both economic resources and environmental value. Furthermore, due to the increasing energy demand, the scarcity of energy supply and the rise of $\mathrm{CO}_{2}$ emissions overdependence on the fossil fuel is becoming a challenge for sustainable development. This also necessitates a new architect of development model.

\section{Green Economy}

The concept of GDP first developed by Simon Kuznets in 1934 as a market value of all final products (goods and services) produced in a given country during a specific period (Farrahi Moghaddam et al., 2013). It is an important parameter for the performance of economic growth of a country. As such, since 1960's, global environmental pollution people recognized that the importance of including value of natural capital into national accounting system (Xu et al., 2010). Thus, the traditional Gross Domestic Product (GDP) cannot reflect the value of natural resources and the environmental loss. Many researchers among others (Kubiszewski et al., 2013), (Talberth \& Bohara, 2006), (Schmalensee, 2012) have pointed out the limitation of GDP as a parameter of economic welfare. As an economic parameter, GDP is limited to measuring a monetary value of final economic products. Because, nations need broader indicators that are compatible with the pillars of sustainable 
development - economic, social, and environmental- (Stockhammer et al., 1997).

To settle this problem, United Nations and the World Bank raised the concept of Green GDP and Green economy. UNEP defined green economy as the economy that results in 'improved human well-being and social equity, while significantly reducing environmental risks and ecological scarcities" (Victor \& Jackson, 2012). It is low-carbon, resource efficient and socially inclusive approach. In green economy, growth in income and employment are driven by public and private investments that reduce carbon emissions and pollution, enhance energy and resource efficiency and prevent the loss of biodiversity and ecosystem services (UNEP, $2011 \mathrm{~b}$ ). Nowadays, the idea that though a trade-off relationship between economic progress and environment al conservation has become less credible (Carfi \& Schilirò 2012).

Modern economic growth considers energy as one determinant factor of production. The interdependence between energy input, environment and economic growth is not straight forward. Economic activity depends on energy inputs for its production and thereby releases $\mathrm{CO}_{2}$ emissions. Emission causes a rise in temperature due to high concentration of $\mathrm{CO}_{2}$ in the atmosphere. The feedback on rise in global temperature leads to climatic change that can cause a reduction in economic resources and growth (Fiddaman, 2002). On the other hand, the gap between rich and poor can have implication in $\mathrm{CO}_{2}$ intensity reduction target. Social equity and environmental targets are non-linearly interrelated. According to WWF (2014) and Victor \& Jackson, (2012), it is considered as a true GE if the objectives of social equity and environment are met.

However, this complex relationship cannot be addressed using the traditional linear approaches. It requires sophisticated method that can integrate social, environment and economic sectors. Hence, this complexity leads to the needs for GE approach that is compatible with synergy of multi-stakeholders (See Table 1). This will be in line with sustainable development, if stakeholders are cooperated and integrated by greening different economic sectors. The ultimate outcome will lead to the significant reduction in GHG emissions UNEP (2011 a).

Table 1. Green economy synergy of stakeholders

\begin{tabular}{lrc}
\hline Society & Economy & Environment \\
\hline Population & Production: Palm oil biomass & Natural capital \\
& & $\bullet$ Reserves \\
\hline Education sector & Government & Energy sector \\
$\bullet \quad$ awareness creation & $\bullet \quad$ Policy intervention & $\bullet$ Energy supply \\
$\bullet \quad$ life style & $\bullet \quad$ Infrastructure & Emissions \\
\hline Health care sector & Private sectors & $\bullet \quad \mathrm{CO}_{2}$ emissions \\
$\bullet \quad$ awareness creation & $\bullet \quad$ Investment on RE & $\bullet$ Emission intensity \\
\hline Urbanization & Household sector & \\
& $\bullet \quad$ Consumption \& saving & \\
& $\bullet \quad$ Employment in RE & \\
\hline
\end{tabular}

Firm

- Sustainable production

- Energy saving

- Energy efficiency

- Low carbon product

Financial sector

- Loan facility for RE investment

Source: UNEP. (2011a). Modeling Global Green Investment Scenarios, Supporting the Transition to a Global Green Economy. 
Compared to brown economy, green economy grows faster while maintaining environmental and natural resources. It is characterized by pro-poor growth investment to realize energy efficiency and resource conservation. Furthermore, green economy has potential to create more jobs than brown economy in the long-tem.

The growth target of green economy is not achieving high income and optimal employment per-se in GE - the objective of investment for the growth of income and employment is constrained by minimizing carbon emissions and pollution; enhancing energy and improving resource efficiency; prevention of the loss of biodiversity UNEP (2011 a) and WWF (2014). Moreover, these investments need to be supported by specified and targeted government expenditures and policies.

Green economy meant inclusive and pro-poor because it focuses on food security and access to basic needs mainly water and electricity. It also focuses on equity in distributing costs and benefits between rich and poor community. Furthermore, it is in line with the MDG and post-MDG global development agenda.

\section{Why Green Economy Approach?}

Green economy is a flexible approach that does not favor the perspective of neither supply side economy nor demand side economy. It is an integrated perspective that is relevant to all economies. It helps in policy formulation and assessment in order to attain sustainable development. It uses to evaluate impact of policies and investments across sectors and economic agents. By doing so it enhances the system's performance rather than single parameter analysis. In addition, since the existing approaches are not appropriate for holistic analysis; GE fulfils the methodological gap of existing models. But unlike other models, it integrates the knowledge cross sectors as well as involve different stakeholders.

Green economy helps for policy analysis during the pre and post implementation of development projects in policy formulation and assessment UNEP (2014 b). To this end, for instance, in the long run, Malaysia is committed to reduce $40 \%$ of $\mathrm{CO}_{2}$ emission with the reference of 2005 level. This standard requires reducing a consistent percentage of carbon emission over time through promoting renewable energy consumption in order to achieve the targeted figure in a specific year. Similarly, in the EU and USA, the objective of fuel efficiency leads to a sustainable improvement of engine efficiency subject to reduction in energy consumption UNEP (2014 b). In this manner, the policy statement of GE supported by specific targets before implementation and evaluated after it implemented.

\section{Green Growth, Green Economy and Sustainable Development}

Green growth is defined by the OECD as "Green growth means fostering economic growth and development while ensuring that natural assets continue to provide the resources and environmental services on which our well-being relies" (OECD, 2011 a). Similarly, (Hallegatte S., 2011) defines green growth as a "making growth processes resource-efficient, cleaner and more resilient without necessarily slowing them".

However, there are some driving factors of green growth. (Jänicke, 2012) listed these factors as the prevention of growth-damaging development, state-induced investments, innovation, the dynamics of future green markets, and resource productivity. Green growth is not a replacing philosophy for the notion of sustainable development. Rather it should be considered as a subset that helps to achieve a targeted economic progress alongside the environment (Schmalensee, 2012).

Since last few decades, the goal of sustainable development has become a major policy objective. However, the sustainable development policy goal is not yet seen in line with the traditional economic and policy objectives (Khan et al., 2013).The notion of sustainable development will be sharpen through considering various stocks of nations at a given period. These stocks would include different types of "renewable and non-renewable natural resources, fixed capital, knowledge, human health, human capital, and environmental quality" (Schmalensee, 2012).

The contemporary notion of economic growth is highly influenced by the neoclassical growth model developed by Robert Solow in the mid-1950s. From the past trend, it is observed that countries' prosper in economic development in the expense of natural capital. The economic growth of nations led to the exploitation of natural resources. Developing countries with resource abundance primarily rely on natural assets (such as land) and economic resources such as (fossil fuels) to fasten their economic growth WWF (2014). According to (UNEP (2011 a) report, the performance of most advanced economies shows that their natural capitals are almost entirely depleted which necessitate them to importation of most basic resources. Furthermore, they are significantly paying cost of substitution for the lost ecosystem services.

However, the principal drivers of GE for economic growth are stocks and flows of natural capita equally with the 
stock of labour and physical capital. In other words, while the accumulation of physical capital is the key driver in traditional economic models, accumulation of natural capital and its utilization rate is the main driver of economic growth in GE approach. "In fact, longer-term sustainable growth is related to the sustainable management of natural resources, such as water, land and fossil fuels. Increasing the efficiency of use and curbing waste of such resources would reduce the decline of stocks, or even support their growth in certain cases" UNEP (2011 a). Accordingly, the promotion of renewable resources enhances the stock of natural resources that can maintain the vulnerability of resource depletion.

Green economy is believed to be the best economic tools to attain sustainable development goals. As any model, it is problem oriented and its starting point is by thinking how the problem will be analyzed and solved. As for $\mathrm{GE}$, it is equally important to specify the impacts that need to be analyzed and assessed in policy formulation before developing the model UNEP (2014 b). GE approach focuses on analyzing the key indicators of pillars of sustainable development. By integrating social, economic and environmental sectors, the analysis will be multi-disciplinary, dynamic and systematic (Table 2).

Table 2. Issue identification and policy formulation in green economy

\begin{tabular}{|c|c|c|}
\hline Stages & Steps & Indicators \\
\hline \multirow{7}{*}{$\begin{array}{l}\text { Problem } \\
\text { identification }\end{array}$} & Identifying critical issue & $\mathrm{CO}_{2}$ emissions ( $\mathrm{kt} \mathrm{CO}_{2}$ equiv) \\
\hline & & Energy consumption (Mt/year) \\
\hline & Assess the issue and its relation to & Fossil fuel reserve (Mt/year) \\
\hline & natural environment & average temperature, Climate change $\left({ }^{\circ} \mathrm{C}\right)$ \\
\hline & Analysing causes of the & Urbanization (\% of urban population) \\
\hline & concerning issues & Fossil fuel subsidies (US\$/year, \% of GDP) \\
\hline & $\begin{array}{l}\text { Analysing how the issue impacts } \\
\text { on society, economy and } \\
\text { environment }\end{array}$ & $\begin{array}{l}\text { Primary sector employment (People/year) } \\
\text { Increase in average temperature }\left({ }^{\circ} \mathrm{C}\right)\end{array}$ \\
\hline \multirow[t]{2}{*}{$\begin{array}{l}\text { Policy } \\
\text { formulation }\end{array}$} & $\begin{array}{l}\text { Identifying desired outcome } \\
\text { (policy objectives) }\end{array}$ & 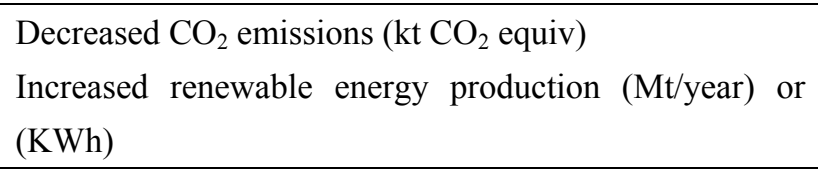 \\
\hline & $\begin{array}{l}\text { Identifying interventions options } \\
\text { and outcome indicators } \\
\text { (scenarios) }\end{array}$ & $\begin{array}{l}\text { Renewable energy: Feed-in-tariffs (US } \$ \mathrm{MWh} \text { ) } \\
\text { Energy efficiency: national standards } \mathrm{CO}_{2} \text { emissions \% } \\
\text { reduction) }\end{array}$ \\
\hline \multirow[t]{3}{*}{$\begin{array}{l}\text { Assessment and } \\
\text { evaluation }\end{array}$} & $\begin{array}{l}\text { Estimating policy impact across } \\
\text { the sector }\end{array}$ & $\begin{array}{l}\text { Reduced cost of energy imports (US\$/year) } \\
\text { Household consumption and savings (US\$/year) }\end{array}$ \\
\hline & $\begin{array}{l}\text { Analysing impact on the overall } \\
\text { well-being }\end{array}$ & $\begin{array}{l}\text { Employment and income generation (US\$/year, } \\
\text { People/year) }\end{array}$ \\
\hline & $\begin{array}{l}\text { Analyzing pros and cons for } \\
\text { decision making }\end{array}$ & $\begin{array}{l}\text { Income creation for rural communities } \\
\text { Cost of intervention (US\$year) } \\
\text { Investment in renewable energy (US\$/year, \% of GDP) } \\
\text { Avoided energy costs from savings (US\$year, \% of } \\
\text { GDP) }\end{array}$ \\
\hline
\end{tabular}

Source: UNEP. (2014 a). Using Indicators for Green Economy Policymaking.

GE approaches support the dual objective of growth and low-carbon development, simultaneously, by reducing $\mathrm{CO}_{2}$ emissions and maintaining natural capital UNEP (2011 a). Notably, in principle GE must be in line with country's priority and development agendas by developing strategies and plans; involving different stakeholders and creating knowledge. GE helps to guide countries towards sustainable development by emphasizing more of 
action oriented strategies than theoretical UNEP 2014 b).

\section{The Inclusiveness of Biomass and Fossil Fuels' $\mathrm{Co}_{2}$ Emissions in the Energy and Environment}

Energy demand and $\mathrm{CO}_{2}$ emissions are increasing at alarming rate, globally. The continued increasing of $\mathrm{CO}_{2}$ emissions could lead to environmental catastrophes such as greenhouse emissions. There are several driving factors of $\mathrm{CO}_{2}$ emissions. However, the most contributing one is fossil fuel based energy consumption and level of economic development. Hence, due research interest has been given to energy-environment nexus across countries and regions (Ramanathan, 2005).

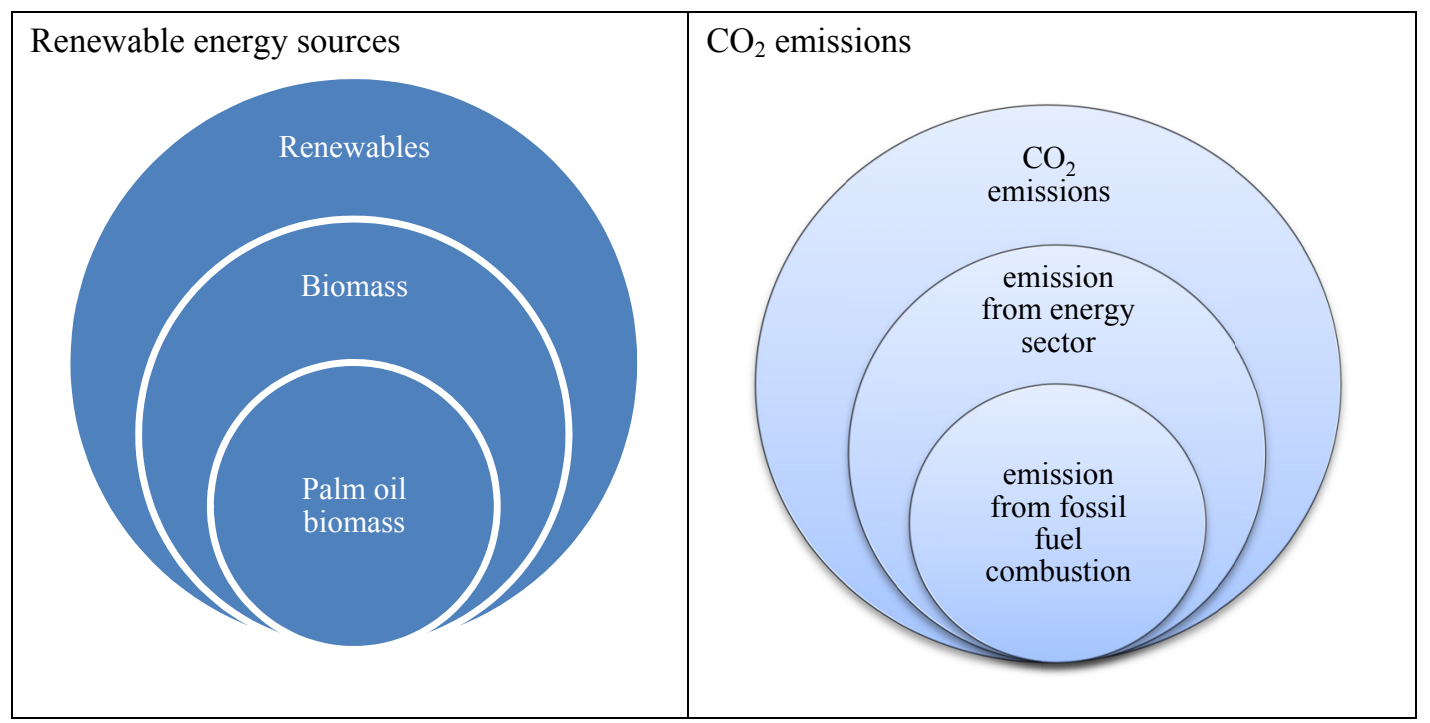

Figure 1. Mutual inclusiveness of $\mathrm{RE}$ and $\mathrm{CO}_{2}$ emissions

Source: The pictorial representation developed by the researcher

The above figure shows that palm oil biomass is a subset of biomass sources and biomass resource is a subset of renewable energy sources. In addition, palm oil biomass accounted for a significant share contributing to biomass. Likewise, the significant source of energy for renewable energy sector is biomass as mentioned in the figure below. Analogously, fossil fuel combustion is the subset of source of emissions for energy sector while emission from energy sector is a subset of $\mathrm{CO}_{2}$ emissions. In addition, fossil fuel combustion is a determinant source of emission for energy sector. Similarly, energy sector is a main culprit for $\mathrm{CO}_{2}$ emissions as discussed below. 


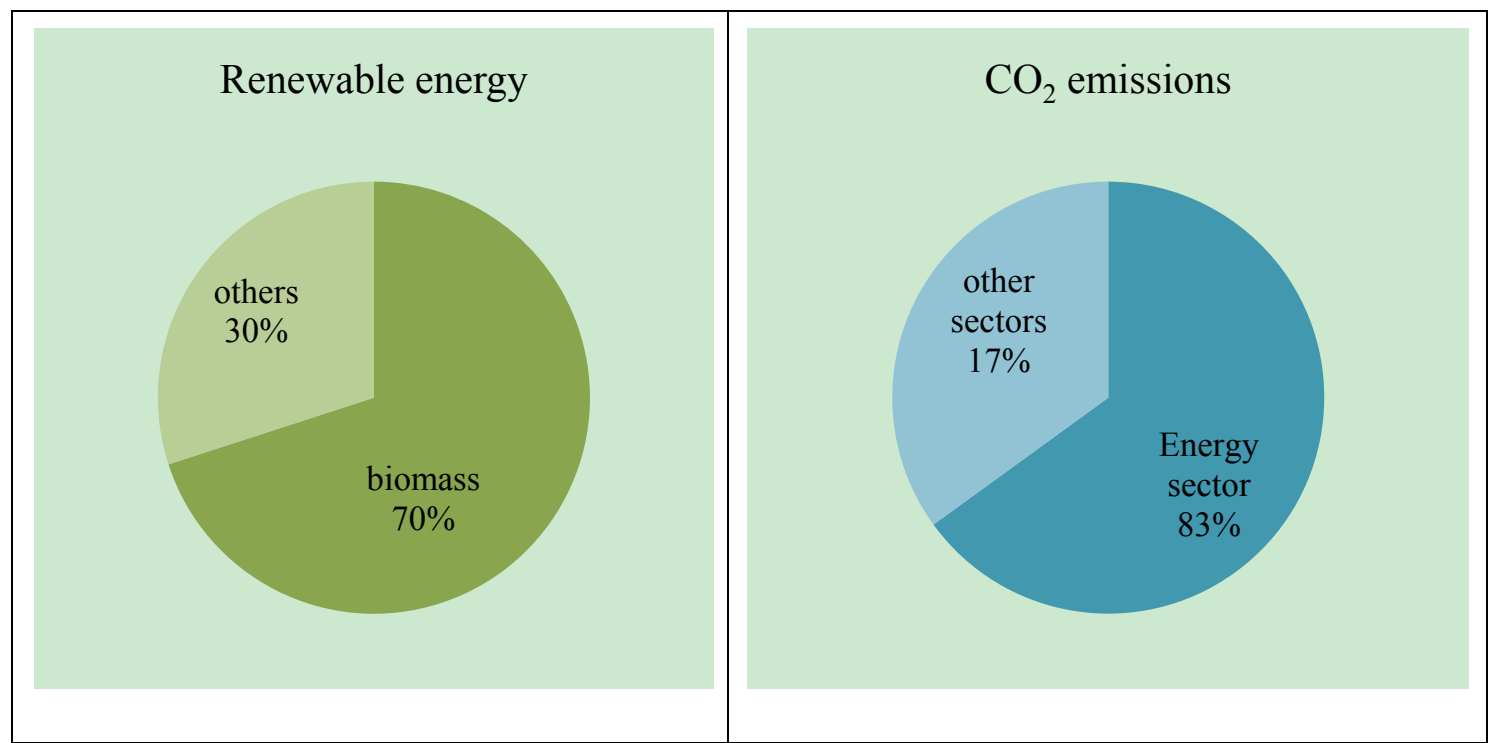

Figure 2. Significant share of $\mathrm{RE}$ and $\mathrm{CO}_{2}$ emissions

Source: International Energy Agency, $\mathrm{CO}_{2}$ emission from fuel combustion highlights, March 2013

Basically the sources of carbon dioxide $\left(\mathrm{CO}_{2}\right)$ emissions are primarily associated to energy sector which is the primary source of GHGs effects (Khan et al. 2013). Whereas the main source of methane $\left(\mathrm{CH}_{4}\right)$ and nitrous oxide $\left(\mathrm{N}_{2} \mathrm{O}\right)$ emissions are agriculture (see Statistical Year Book Asia Pacific Country, 2013). According to (Zilio $\&$ Recalde, 2011) energy sector alone may be responsible for $77 \%$ out of total $\mathrm{CO}_{2}$ emissions.

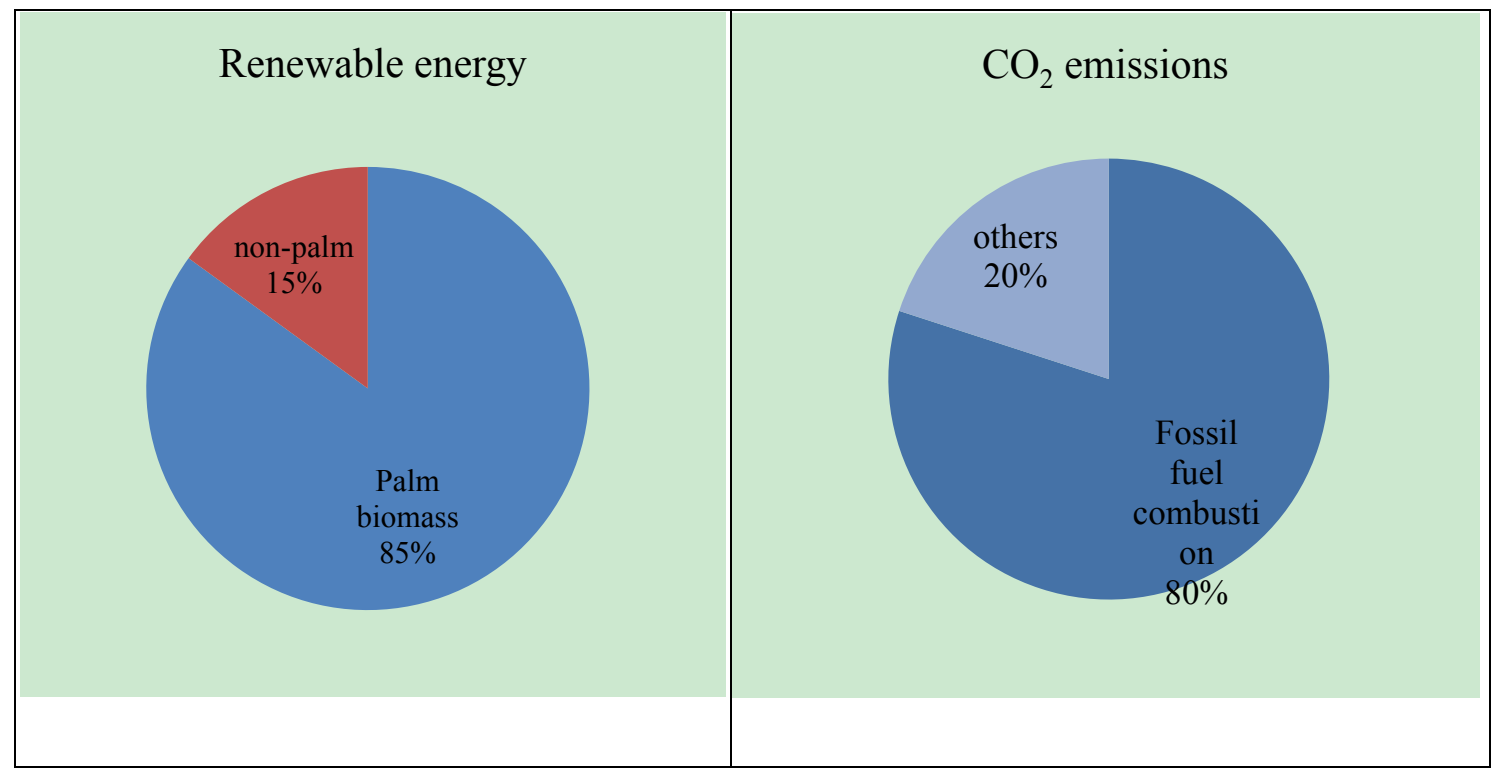

Figure 3. Significant source of $\mathrm{RE}$ and $\mathrm{CO}_{2}$ emissions

Source: International Energy Agency (IEA), 2010

In 2010, IEA reported that $\mathrm{CO}_{2}$ emission from fuel combustion is $76 \%$ out of total energy pollutants. The burning of fossil fuel such as coal, oil and natural gas increases carbon dioxide to the atmosphere. Chemical reactions and land use changes are considered as notorious factors contributing to the release of carbon dioxide emission to the atmosphere. Empirical findings reveal that $\mathrm{CO}_{2}$ alone accounted as a cause for about 70 percent of greenhouse gases, and fossil foil consumption is responsible for about 80 percent for rising atmospheric $\mathrm{CO}_{2}$ (Alam et al. 2011). Similarly researchers such as (Ozturk\&Acaravci 2010) and (Saboori\&Sulaiman 2013) have found that carbon dioxide $\left(\mathrm{CO}_{2}\right)$ emissions is responsible for about $60 \%$ of GHGs effects. 


\section{Biomass and Renewable Energy, the Case of Malaysia}

Renewable energy and the conversion of solid waste to energy are among the major elements of green economy (Chapple, 2008). Though the supply of conventional energy source is scarce, the energy consumption has increasing trend, globally. In line with this, International Energy Agency (IEA) projected that the global energy consumption would increase more than $50 \%$ in 2030 taking the current consumption level as a reference (Oh, Pang, \& Chua, 2010).

In the case of ASEAN countries, the primary energy demand is expected to rise by 76 per cent between 2007 and 2030 while the global primary energy demand is expected to rise at the rate of 1.6 per cent annually. For instance, the energy demand for China alone amount to 30 per cent of the total energy demand of developing countries (UNDP, 2007); (Lim \& Joseph, 2010). Similarly, the energy consumption of Malaysia is tremendously increasing following rapid economic growth of the country (Oh, Pang, \& Chua, 2010). Moreover, the national developmental plan called vision 2020 will lead to high energy demand. In order to sustain energy supply along with clean environment, the country has to promote alternative energy source instead of that of conventional energy sources.

Asian countries including Malaysia have huge potential to develop renewable energy sector. To this end, Malaysia has started to discover new technologies in order to develop this untapped potential. (Siti Khadijah Najid \& Sopian, 2009). Enhancing the alternative renewable energy sources like oil palm biomass will have dual purposes that are greening the economy and fulfilling the gap of energy supply. For instance, biomass fuels contribute more than 15 per cent of the energy consumption in the country. To this end, the abundant biomass resources of Malaysia are used to produce steam for processing activities and production of electricity.

Malaysia is a world leading palm oil producer. Palm tree provides $10 \%$ of palm oil and $90 \%$ of biomass - that is full of fibre and cellulose that produces steam for power generation in palm oil mills (Milbrandt \& Overend, 2008); (Sumathi, Chai \& Mohamed, 2008). The biomass from palm oil industry is a promising sustainable energy resource. As a world leading producer of palm, Malaysia has huge potential to utilize the palm oil biomass to generate an alternative energy (Koh \& Lim, 2010). In 2010, the annual production of dry palm oil biomass amounted to 80 million tonnes and its production is projected to increase to 100 million tonnes annually by 2020 (Umer et al., 2013).

\section{Conclusion}

Since the traditional economic approaches are not appropriate for holistic analysis; green economy approach fulfils the methodological gaps that exist in the growth models. Traditionally, the relationship between economic growth and environment are considered as trade-off relation. The main and primary motive of producers was solely profit maximization. However, green economy approach focuses on analysing the key indicators of pillars of sustainable development by integrating social, economic and environmental elements. It is believed to be the best economic tools to attain sustainable development goals. Green economy is the clean energy economy which mainly emphasizes on renewable energy and energy efficiency. To this end, energy sector is considered as a key player in determining the greenness of the economy and thereby sustainability. The term 'green economy' is not interchangeably used with 'sustainable development'. However, both concepts are mutually inclusive where achieving sustainability is almost determined by the indicators of green economy.

\section{Acknowledgement}

Financial assistance provided by the Rural Transformation Grant (Ref. No. AP-2014-017) Institute for Environment and Development (LESTARI), Universiti Kebangsaan Malaysia headed by Emeritus Prof. Chamhuri Siwar is gratefully acknowledged.

\section{References}

Alam, M. J., Begum, I. A., Buysse, J., Rahman, S., \& Van Huylenbroeck, G. (2011). Dynamic Modeling of Causal Relationship between Energy Consumption, $\mathrm{CO}_{2}$ Emissions and Economic Growth in India. Renewable and Sustainable Energy Reviews, 15(6), 3243-3251.http://dx.doi.org/10.1016/j.rser.2011.04.029

Carfì, D., \& Schilirò, D. (2012). A Coopetitive Model for the Green Economy. Economic Modelling, 29(4), 1215-1219. http://dx.doi.org/10.1016/j.econmod.2012.04.005

Chapple, K. (2008). Defining the Green Economy: A Primer on Green Economic Development. Center for Community Innovation, Berkeley. 
Farrahi Moghaddam, R., Farrahi Moghaddam, F., \& Cheriet, M. (2013). A Modified Ghg Intensity Indicator: Toward a Sustainable Global Economy Based on a Carbon Border Tax and Emissions Trading. Energy Policy, 57(0), 363-380. http://dx.doi.org/10.1016/j.enpol.2013.02.012

Fiddaman, T. S. (2002). Exploring Policy Options with a Behavioral Climate-Economy Model. System Dynamics Review, 18(2), 243-267.http://dx.doi.org/10.1002/sdr.241

Hallegatte S., H. G., Fay, M., \& Treguer, D. (2011). From Growth to Green Growth: A Framework. Policy Research Working Paper, 5872.

Jänicke, M. (2012). "Green Growth”: From a Growing Eco-Industry to Economic Sustainability. Energy Policy, 48(0), 13-21.http://dx.doi.org/10.1016/j.enpol.2012.04.045

Khan, M. A., Khan, M. Z., Zaman, K., Khan, M. M., \& Zahoor, H. (2013). Causal Links between Greenhouse Gas Emissions, Economic Growth and Energy Consumption in Pakistan: A Fatal Disorder of Society. Renewable and Sustainable Energy Reviews, 25(0), 166-176. http://dx.doi.org/10.1016/j.rser.2013.04.002

Koh, S. L., \& Lim, Y. S. (2010). Meeting Energy Demand in a Developing Economy without Damaging the Environment-a Case Study in Sabah, Malaysia, from Technical, Environmental and Economic Perspectives. Energy Policy, 38(8), 4719-4728. http://dx.doi.org/10.1016/j.enpol.2010.04.044

Kubiszewski, I., Costanza, R., Franco, C., Lawn, P., Talberth, J., Jackson, T., \& Aylmer, C. (2013). Beyond Gdp: Measuring and Achieving Global Genuine Progress. Ecological Economics, 93(0), 57-68. http://dx.doi.org/10.1016/j.ecolecon.2013.04.019

Lim, M. H. Joseph. (2010). A Case Study on Palm Empty Fruit Bunch as Energy Feedstock. Faculty of Arts and Sciences, Harvard University. USA: SEGi Review, 3(2), 3-15.

Milbrandt, A., \& Overend, R. P. (2008). Survey of Biomass Resource Assessments and Assessment Capabilities in APEC Economies. APEC Energy Working Group. http://dx.doi.org/10.2172/949876

OECD. (2011 a). Towards Green Growth: A Summary for Policy Makers. OECD, Paris.

Oh, T. H., Pang, S. Y., \& Chua, S. C. (2010). Energy Policy and Alternative Energy in Malaysia: Issues and Challenges for Sustainable Growth. Renewable and Sustainable Energy Reviews, 14(4), 1241-1252. http://dx.doi.org/10.1016/j.rser.2009.12.003

Ozturk, I., \& Acaravci, A. (2010). Co2 Emissions, Energy Consumption and Economic Growth in Turkey. Renewable and Sustainable Energy Reviews, 14(9), 3220-3225.http://dx.doi.org/10.1016/j.rser.2010.07.005

Ramanathan, R. (2005). An Analysis of Energy Consumption and Carbon Dioxide Emissions in Countries of the Middle East and North Africa. Energy, 30(15), 2831-2842. http://dx.doi.org/10.1016/j.energy.2005.01.010

Saboori, B., \& Sulaiman, J. (2013). Environmental Degradation, Economic Growth and Energy Consumption: Evidence of the Environmental Kuznets Curve in Malaysia. Energy Policy, 60(0), 892-905. http://dx.doi.org/10.1016/j.enpol.2013.05.099

Schmalensee, R. (2012). From "Green Growth" to Sound Policies: An Overview. Energy Economics, 34, Supplement 1(0), S2-S6.

Statistical Year Book Asia Pacific Country. (2013).

Stockhammer, E., Hochreiter, H., Obermayr, B., \& Steiner, K. (1997). The Index of Sustainable Economic Welfare (Isew) as an Alternative to Gdp in Measuring Economic Welfare. The Results of the Austrian (Revised) Isew Calculation 1955-1992. Ecological Economics, 21(1), 19-34. http://dx.doi.org/10.1016/S0921-8009(96)00088-2

Sumathi, S., Chai, S. P., \& Mohamed, A. R. (2008). Oil Palm as A Source of Renewable Energy in Malaysia. Renewable and Sustainable Energy Reviews, 12, 2404-3421. http://dx.doi.org/10.1016/j.rser.2007.06.006

Talberth, J., \& Bohara, A. K. (2006). Economic Openness and Green Gdp. Ecological Economics, 58(4), 743-758. http://dx.doi.org/10.1016/j.ecolecon.2005.09.002

Umar, M. S., Jennings, P., \& Urmee, T. (2013). Strengthening the Palm Oil Biomass Renewable Energy Industry in Malaysia. Renewable Energy, 60(0), 107-115. http://dx.doi.org/10.1016/j.renene.2013.04.010

UNDP. (2007). Malaysia Generating Renewable Energy from Palm Oil Waste. Malaysia Report, United Nations Development Programme, Malaysia.

UNEP. (2011). Towards a Green Economy: Pathways to Sustainable Development and Poverty Eradication. 
UNEP. (2011a). Modeling Global Green Investment Scenarios, Supporting the Transition to a Global Green Economy.

UNEP. (2012a). Green Economy Briefing Paper, Metrics \& Indicators.

UNEP. (2014a). Using Indicators for Green Economy Policymaking.

UNEP. (2014b). Using Models for Green Economy Policymaking.

Victor, P. A., \& Jackson, T. (2012). A Commentary on Unep's Green Economy Scenarios. Ecological Economics, 77(0), 11-15. http://dx.doi.org/10.1016/j.ecolecon.2012.02.028

WWF. (2014). Green Economy Modelling of Ecosystem Services in the Dawna Tenasserim Landscape (Dtl). KnowlEdge Srl, Italy.

Xu, L., Yu, B., \& Yue, W. (2010). A Method of Green Gdp Accounting Based on Eco-Service and a Case Study of Wuyishan, China. Procedia Environmental Sciences, 2(0), 1865-1872. http://dx.doi.org/10.1016/j.proenv.2010.10.198

Zilio, M., \& Recalde, M. (2011). Gdp and Environment Pressure: The Role of Energy in Latin America and the Caribbean. Energy Policy, 39(12), 7941-7949. http://dx.doi.org/10.1016/j.enpol.2011.09.049

\section{Copyrights}

Copyright for this article is retained by the author(s), with first publication rights granted to the journal.

This is an open-access article distributed under the terms and conditions of the Creative Commons Attribution license (http://creativecommons.org/licenses/by/3.0/). 